\section{Blintsov V., \\ Blintsov O., \\ Sokolov V.}

\title{
SYNTHESIS OF TOWED UNDERWATER VEHICLE SPATIAL MOTION AUTOMATIC CONTROL SYSTEM UNDER UNCERTAINTY CONDITIONS
}

Об'єктом дослідження є просторовий рух буксируваного підводного апарата (БПА), який працює у складі буксируваної підводної системи (БПС). Структура БПА не містить рушійних пристроїв, до руху він приводиться судном-буксирувальником через кабель-буксир. Задачею керування БПА є забезпечення бажаної динаміки його поступального переміщення. Ручний режим керування дає змогу виконувати лише короткострокові місії та не виключає виникнення помилок оператора при керуванні. Для виконання довготривалих підводних місій необхідно застосовувати автоматизовані БПА.

Для синтезу регуляторів системи автоматичного керування (САК) використовувався метод мінімізацї локальних функціоналів. Він дає змогу отримувати закони керування без інформацій про структуру та параметри математичної моделі об'єкта керування. Для дослідження синтезованої САК використовувався метод імітаційного моделювання із застосуванням комп'ютерної симуляцї. Він дає змогу оцінити якість роботи САК без суттєвих фінансових затрат, необхіднх для морсъкого натурного експерименту.

Синтезовано САК просторовим рухом БПА, яка забезпечує достатню точність керування вертикальною та боковою координатами БПА в умовах невизначеності. Для ї синтезу та роботи не потрібна інформація про структуру та параметри математичної моделі об'єкта керування. Закон керування, на основі якого синтезувались регулятори САК, не містить у своєму складі інформації про похідні керованої величини. Тому контури зворотних зв'язків синтезованої САК мають простішу структуру у порівнянні з САК, синтезованих на основі відомих методів, які використовують координати фазового простору об'єкта.

Досліджено динаміку роботи синтезованої САК просторовим рухом БПА при різних швидкостях буксирування. Тривалість перехідних процесів від моменту виходу САК із зони насичення до моменту потрапляння похибки керування в допустимий діапазон та точність керування є цілком задовільними. У порівнянні з відомими САК просторовим рухом підводними апаратами, синтезована САК не потребує математичної моделі об’єкта керування для ї̈ синтезу та роботи.

ключові слова: буксируваний підводний апарат, система автоматичного керування, просторовий рух, умови невизначеності.

\section{Introduction}

Towed underwater systems (TUS) are successfully used to perform underwater exploration in large areas of marine areas. They have several advantages for this type of work compared to remotely operated and autonomous underwater vehicles [1,2]. The carrier of technological equipment in the TUS is a towed underwater vehicle (TUV), which can carry out:

- hydroacoustic, magnetometric and visual search for underwater objects;

- observation of the underwater environment and underwater objects;

- measurement of oceanographic and geophysical characteristics of the oceans;

- prospecting and exploration of minerals;

- photo, video and hydroacoustic documentation and mapping of the seabed and sunken objects.

Modern technological equipment of TUV (specialized sensors, video cameras, etc.) allow receiving the necessary information in real time. To ensure the quality of their operation, the carrier of the process equipment, that is, the unit, should be able to carry out long-term controlled motion in the underwater space with given dynamic para- meters [3]. At the same time, the TUS with TUV operates under conditions of uncertainty of external disturbances and the non-stationarity of its own operational parameters. Quality control of such an object in manual mode is not always possible. In this regard, the automation of the control of the spatial motion of the unit is an actual scientific problem.

\section{The object of research and its technological audit}

The object of research is the TUV spatial motion, which operates as part of the TUS. The design feature of the TUV is the absence of propulsive devices, in this regard, they are driven by the tugboat (TB), which moves with speed $\vec{v}_{\text {tow }}$ through the cable-tug (CT) (Fig. 1) [4, 5].

The main task of the TUV control is ensuring the desired dynamics of its translational motion. The TUV «Planer-2» project is considered [6]. As a control object, it has two controlled degrees of mobility:

- translational motion in a vertical plane (controlled depth change);

- translational motion in the horizontal plane (controlled lateral motion). 


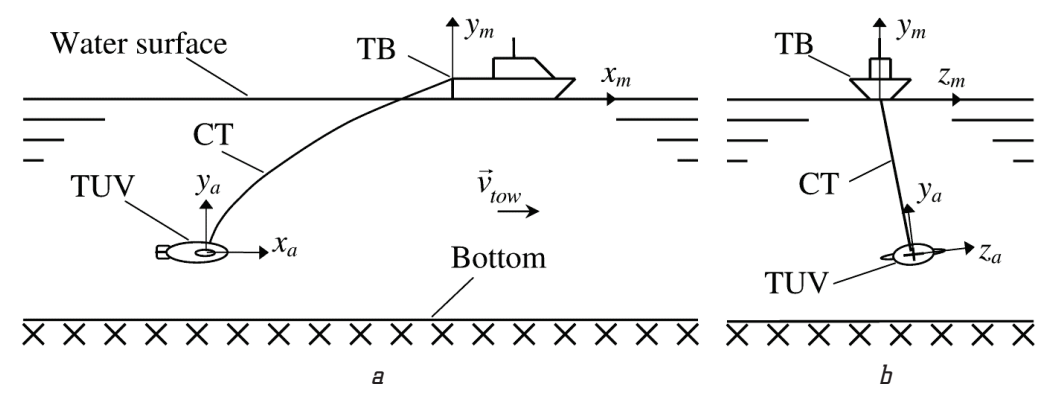

Fig. 1. Single-link towed underwater system: $a$ - view of the starboard; $b$ - view of the stern

An automated electric drive is used to rotate each control wing.

The control action for the «Planer-2» project unit is a row vector $\bar{u}$ :

$$
\bar{u}=\left\{u_{\text {left }}, u_{\text {right }}\right\} ; u_{\text {left }} \in[-1,1] ; u_{\text {right }} \in[-1,1],
$$

where $u_{\text {left }}$ - the control signal for the left control wing; $u_{\text {right }}$ - the control signal of the right control wing.

At the same time, when $u_{\text {left }}=u_{\text {right }}$, the TUV roll is zero and only the TUV depth is controlled by changing the TUV pitch. The latter, in this case, is guided by a synchronous change of control actions for the left and right wings. If $u_{\text {left }} \neq u_{\text {right }}$, then there will be a roll and TUV to shift to the side. Thus, the control of rotating degrees of freedom (roll and pitch) is the basis for controlling the translational degrees of freedom (vertical and lateral motion) of the unit.

Manual operation is only possible when performing short-term underwater missions. In this case, even an experienced operator can't always provide certain modes of motion and can make mistakes in the control. Long-term underwater missions are possible only under the condition of shift work of operators or using TUS with an automated TUV. As a control object, TUV is a substantially nonlinear object that operates under uncertainty conditions. Therefore, automatic control systems (ACS) synthesized on the basis of classical methods are not able to provide the necessary quality control.

\section{The aim and objectives of research}

The aim of research is automation of towed underwater vehicle spatial translational motion control without the use of derivatives of controlled quantities under uncertainty conditions.

To achieve this aim in this paper it is necessary to solve the following objectives:

1. To synthesize controllers of translational and rotating controlled parameters of the towed underwater vehicle.

2. To synthesize ACS of TUV spatial motion under uncertainty conditions.

3. By the method of computer simulation to investigate the dynamics of the synthesized ACS.

\section{Research of existing solutions of the problem}

A lot of scientific publications are devoted to the synthesis of automatic control systems for underwater vehicles and systems.
The TUV automatic control system based on the observer with a high gain and linear-quadratic-integral controller is proposed in [7]. The synthesis of the controller involves the use of a mathematical model of the control object and is complicated under uncertainty conditions. In addition, in the model of the control object, the authors apply the method of lumped masses and springs, which requires significant computational resources for modeling inextensible CTs.

The process of controlling the launch system to stabilize the TUV depth is described in work [8]. The controller is synthesized by presenting the system «CT - TUV» by a low pass filter. However, the issue of controlled changes in the spatial coordinates of the unit is not considered.

The automatic control system for the course of a selfpropelled underwater vehicle based on a proportionalintegral-differential (PID) controller is developed in [9]. It provides smooth course control at low speed, but is sensitive to the parametric errors of the mathematical model and does not provide high control accuracy.

For the ACS synthesis of self-propelled underwater vehicles and other marine moving objects the method of control in the sliding mode is used. The paper [10] is devoted to automating the control of unmanned surface vessels. The system of automatic control of the underwater vehicle motion is proposed in [11]. The main disadvantage of control in the sliding mode is the effect of high-frequency switching of the control action between its limiting values, which limits its application.

The system of high-precision control of the depth of the underwater vehicle based on an adaptive fuzzy regulator in the sliding mode with a softened effect of high-frequency switching is proposed in [12] and developed in [13]. But quality control is provided in a limited range of controlled parameters, the own parameters of the object and the external environment. Indefinite disturbances easily deduce the control object by the indicated limits.

The paper [14] is devoted to an experimental study of the TUV controlled motion, but the control system is implemented only for the vertical coordinate. The TUV spatial motion is not considered.

The integrated ACS of the marine complex is proposed in [15], however, the process of synthesis of the ACS executive level controllers in this work is not given.

The automatic control system based on the PID controller of underwater vehicle is proposed in [16]. The information required for the controller is obtained from a high gain observer. However, the obtained result is not suitable for use under uncertainty conditions, since the synthesis requires a mathematical model of the control object. 
Analysis of literature data shows that scientific publications are mainly devoted to the automation of selfpropelled underwater vehicles. However, to ensure high dynamic accuracy, control laws are applied, which are synthesized on the basis of a mathematical model of the control object and contain derivatives of a controlled quantity. The issue of automatic control of TUV spatial motion under uncertainty conditions is currently almost unexplored.

\section{Methods of research}

5.1. Development of the generalized ACS structure of multidimensional TUV motion. The dynamics of the TUV translational motion as a solid body, according to the basic law of dynamics, obeys a system of second-order differential equations, which is described in detail in [17].

However, TUV as controlled object has the following feature. The translational motion of the unit arises from the action of forces that arise as a result of the TUV interaction with the $\mathrm{CT}$ and the oncoming flow of water. Primary forces appear on the TUV from the CT, mov the TUV in relation to the aquatic environment. As soon as the speed of TUV motion with respect to water takes non-zero values, hydrodynamic forces immediately appear on the TUV body, its bearing surfaces (BS) and tail unit (TU). To control the TUV translational motion, it is necessary to change the vector of the resultant force $\vec{F}$ in a controlled manner. Since the TUV does not have moving devices, the only way to change $\vec{F}$ in a controlled manner is changing the TUV angular orientation. The main hydrodynamic forces arise BS, fixedly mounted on the TUV body. The tail unit allows changing the vector of the resultant force $\vec{F}$ due to a change in the TUV angular orientation. Thus, the translational TUV kinematic parameters are controlled by controlled change of the TUV rotating kinematic parameters. In this regard, the TUV as a control object is a multi-dimensional object of the fourth order. Its rotational motion obeys the system of second-order differential equations and is the cause of the change in the vector of the resultant force $\vec{F}$. The translational motion, in turn, is also described by a system of second-order differential equations, and forms the fourth order of the control object.

TUV navigation devices allow to measure TUV rotating and translational coordinates, which allows to provide appropriate feedback. Therefore, let's synthesize the ACS of the TUV spatial motion by applying the principle of subordinate control. Decomposition of the reference model [18] allows to select the main control circuit of the 2nd order for translational motion and the embedded control circuit of the 2nd order for rotational motion (Fig. 2).
The control task in the form of a given vertical $y_{g}(t)$ and lateral $z_{g}(t)$ coordinates arrives at the TUV translational motion controller. The object of control for the regulator of translational motion is the unit, automated with rotating degrees of freedom. Therefore, the translational motion controller generates the control actions in the form of a given value for the pseudo-roll $\theta_{g}^{\prime}$ and the pseudo-pitch $\psi_{g}^{\prime}$ for the TUV rotational motion ACS (the essence of the parameters $\theta_{g}^{\prime}, \theta^{\prime}, \psi_{g}^{\prime}$ and $\psi^{\prime}$ will be considered later). The variables $\theta_{g}^{\prime}$ and $\psi_{g}^{\prime}$ form the control task for the rotational motion controller, which generates control actions $\bar{u}$ directly for the TUV. The specified ( $y_{g}$ and $z_{g}$ ) and actual ( $y$ and $z$ ) TUV coordinates are given in the $O_{m} x_{m} y_{m} z_{m}$ intermediate coordinate system (ICS) - coordinate system intermediated with the TB. Also, when controlling the TUV, the $O_{a} x_{a} y_{a} z_{a}$, body axis coordinate system (BCS) is applied, which moves and rotates together with the TUV, and the $O_{c} x_{c} y_{c} z_{c}$ cable coordinate system (CCS), which is formed depending on the relative position of the TB and the TUV. The coordinate systems and the equations of the relations between them are considered in detail in [17, 19].

For the synthesis of second-order regulators, which are part of the ACS, we apply the control law synthesized on the basis of the method of minimizing local functionals [20]. It allows providing high dynamic accuracy in conditions of uncertainty without the use of derivatives of a controlled variable [21]:

$$
\begin{aligned}
& u(\widehat{u})=\left\{\begin{array}{l}
\hat{u}, \text { at } \hat{u} \in[-1,1] ; \\
\operatorname{sign}(e), \text { otherwise; }
\end{array}\right. \\
& s(\widehat{u})=\left\{\begin{array}{l}
\text { false, at } \hat{u} \in\left[-K_{s}, K_{s}\right] ; \\
\text { true, otherwise; }
\end{array}\right. \\
& \hat{u}:=\sigma k\left(e+\frac{2}{T_{r}} e_{i}\right)+I_{\chi}(\chi, s, 0, t) ; \\
& e_{i}:=I_{e}\left(e, s, e_{i I C}, t\right) ; \quad \chi=\frac{\sigma k}{T_{r}^{2}} e_{i}-h u ; \\
& e_{i I C}=\frac{T_{r}}{2 \sigma k}\left[K_{s} \operatorname{sign}(e)-\sigma k e\right] ; \\
& k>0 ; \quad \sigma=\operatorname{sign}\left(\frac{\partial \ddot{y}}{\partial u}\right) ; \quad K_{s} \geq 1,
\end{aligned}
$$

where $u$ - the limited value of the control action; $\hat{u}-$ unlimited value of the control action; $s$ - flag of the control circuit saturation; $e-$ the control error; $K_{s}-$ coefficient of expansion of the zone of allowable $\hat{u}$ values; $\sigma-$ a parameter that ensures the fulfillment of the sign rule (detailed information about the sign rule is set forth in [20]); $k, h$ - coefficients of the contour of the control function; $T_{r}$ - the time constant of the ACS reference model; $e_{i}$ - the integral of the control error; $e_{i I C}-$ the initial value for the integrator of the parameter $e$; $\chi-a$ variable that denotes the integrand of the second integral of the control law; $y$ - a controlled quantity, the second time derivative is indicated by two points above the variable; $\operatorname{sign}(\cdot)$ - the function of taking a sign; $I_{x}\left(x, s, x_{I C}, t\right)$ - the integration function.
Fig. 2. The generalized structure of the automatic control system (ACS) of the towed underwater vehicle (TUV) translational motion 
The integration function $I_{x}\left(x, s, x_{I C}, t\right)$ takes the following arguments:

- the first argument is an integrated variable;

- the second argument is a flag of saturation;

- the third argument is the initial integration condition, the integrator output takes the $x_{I C}$ value with $s=$ true;

- the last argument is time.

5.2. ACS synthesis of TUV spatial motion. The ACS synthesis of rotational motion on the basis of the control law (1) provides for the adjustment of the pseudo-roll and the pseudo-pitch controllers and the coordination of their operation. The outputs of the pseudo-roll $u_{\theta}$ and the pseudopitch $u_{\psi}$ controllers are coordinated as follows:

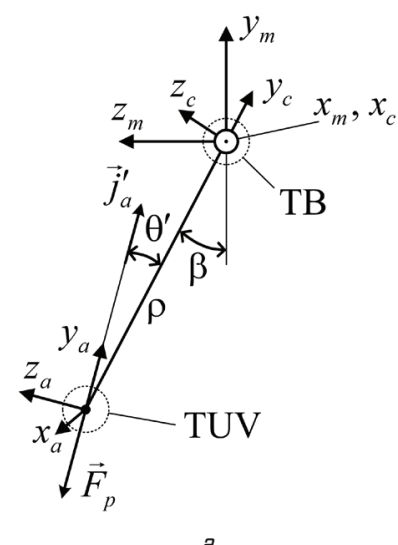

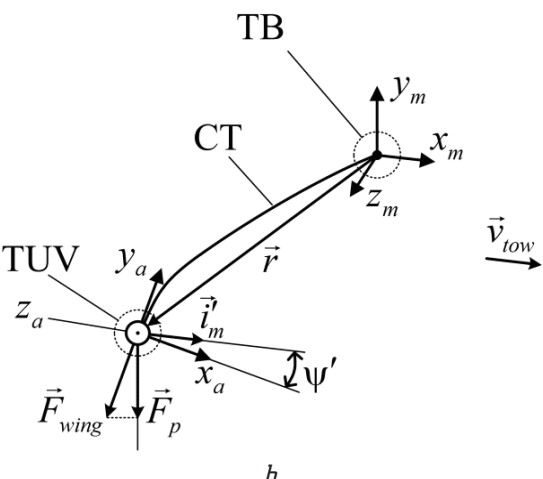

$$
u_{\text {left }}=u_{\psi}-u_{\theta} ; \quad u_{\text {right }}=u_{\psi}+u_{\theta}
$$

$a$ - TUS elements in the $Q_{m} y_{m} z_{m}$ plane of the intermediate coordinate system; $b$ - TUS elements in the $D_{a} x_{a} y_{a}$ plane of the BCS

The adjustment of the initial conditions is carried out in the controller with a larger error. In other words, if $s=$ true, then the initial conditions are reset (that is, the initial condition is fed as the output value) to the controller integrators, to which input a larger error arrives.

The TUV translational motion is considered in the ICS $O_{m} x_{m} y_{m} z_{m}$, in conjunction with the TB hull. Controlled translational motion of the unit is carried out in the transverse plane of the ICS $O_{m} y_{m} z_{m}$. It is necessary to find out how the control signals received at the output of the regulator of translational motion, that is, variables $\theta_{g}^{\prime}$ and $\psi_{g}^{\prime}$, affect the control parameters of the unit, that is, the variables $y$ and $z$ (Fig. 2).

Let's analyze the TUV motion dynamics. If roll is set to the left side $(\theta<0)$, then the TUV moves to the right, if roll is set to the right side $(\theta>0)$, then the TUV moves to the left. If pitch is set to the bow, then the TUV will move deeper, if pitch is set to the stern, then the TUV will move to the surface.

In general, TU allows to control the angular accelerations $\dot{\omega}_{x}$ and $\dot{\omega}_{z}$. And the influence of the angular velocities $\omega_{x}$ and $\omega_{z}$ on the TUV angular orientation depends on the current values of the TUV Euler angles. If the unit has a roll on one of the sides $\theta= \pm 90^{\circ}$, then the pitch will be uncontrolled and the TUV will not be able to carry out controlled immersion, but it will be possible to control the TUV lateral coordinate $O_{m} z_{m}$.

The control force $\vec{F}_{p}$ that ensures the TUV motion in the $O_{m} y_{m} z_{m}$ plane is formed by the bearing surface. Analysis of the TUV motion dynamics shows the following:

- TUV rotation around the axis $O_{a} x_{a}$ associated with the TUV allows control of the direction of $\vec{F}_{p}$ in the $O_{m} y_{m} z_{m}$ plane;

- TUV rotation around the axis $O_{a} x_{a}$ associated with the TUV allows to control the absolute value of $\vec{F}_{p}$ and change its direction to the opposite in the $O_{m} y_{m} z_{m}$ plane.

Taking into account the peculiarity of the influence of the control force $\vec{F}_{p}$ on the TUV translational motion in the TUV translational motion controller, it is proposed to apply the polar coordinate system when forming the control task and feedback signals (Fig. 3, a).

The symbol «९» indicates that the axis it designates is directed in the direction of the observer. It is considered that the $O_{m} x_{m}$ axis coincides with the towing speed $\vec{v}_{\text {towe }}$, since the TB is moving with its nose against the oncoming flow of water.
The distance between the $\mathrm{TB}$ and the projection of the center of mass of the TUV on the $O_{m} y_{m} z_{m}$ plane is indicated by the variable $\rho$ :

$$
\rho=\sqrt{y^{2}+z^{2}},
$$

where $y$ and $z$-controlled TUV coordinates in the ICS.

Angle $\beta$ is the angle between the radius vector, which connects the TB with the projection of the center of mass of the TUV on the $O_{m} y_{m} z_{m}$ plane, and the ICS vertical axis $O_{m} y_{m}$, taken in the opposite direction:

$$
\begin{aligned}
& \beta=f_{\text {polar }}(-y,-z) ; \\
& f_{\text {polar }}(a, b)=\left\{\begin{array}{l}
\operatorname{arctg} \frac{b}{a}, \text { if } a>0 ; \\
\operatorname{arctg} \frac{b}{a}+180^{\circ}, \text { if } a<0 \wedge b \geq 0 ; \\
\operatorname{arctg} \frac{b}{a}-180^{\circ}, \text { if } a<0 \wedge b<0 ; \\
90^{\circ}, \text { if } a=0 \wedge b>0 ; \\
-90^{\circ}, \text { if } a=0 \wedge b<0 ; \\
\text { uncertainty, if } a=0 \wedge b=0,
\end{array}\right.
\end{aligned}
$$

where $f_{\text {polar }}(\cdot)$ - a function that calculates the polar angle based on Cartesian coordinates in the range $\left(-180^{\circ}, 180^{\circ}\right.$; $a, b$ - the arguments of the $f_{\text {polar }}(\cdot)$ function.

This definition of $\beta$ gives $\beta<0$ for $z>0$ and $\beta>0$ for $z<0$. This is necessary so that the roll $\operatorname{sign} \theta$ coincides with the acceleration sign of the parameter $\beta$.

Thus, the current TUV coordinates are formed by the pair $\{\rho, \beta\}$. The given TUV coordinates are formed by the pair $\left\{\rho_{g}, \beta_{g}\right\}$ and are obtained in a similar way on the basis of the given Cartesian coordinates $x_{g}$ and $y_{g}$.

To control the direction of $\vec{F}_{p}$ let's introduce the pseudoroll angle $\theta^{\prime}$. It is formed between the vector $\vec{j}_{a}^{\prime}$ and the projection of the radius vector $\vec{r}$ connecting the TB to the TUV, on the $O_{m} y_{m} z_{m}$ plane (Fig. $3, a$ ). The vector $\vec{j}_{a}^{\prime}$ is a projection of the basic vector $\hat{j}_{a}$ of the BSC on the $O_{c} y_{c} z_{c}$ plane of the CCS (as well as on the $O_{m} y_{m} z_{m}$ plane of the ICS).

To calculate the parameter $\theta^{\prime}$, let's apply the cable coordinate system. First, find the coupling matrix between 
the ICS and CCS $K_{C M}$. Unit vector of the CCS abscissa axis $\hat{i}_{c}$ coincides with the corresponding $\hat{i}_{m}$ ICS unit vector:

$$
\hat{i_{c}}=\left\{i_{c . x . m}, i_{c . y . m}, i_{c . z . m}\right\}_{M}=\{1,0,0\}_{M} .
$$

Hereinafter, to denote the coordinates of the basis vectors we apply the following notation. The first character of the index indicates which base the base vector represents. The symbol through the point indicates the axis (abscissa $x$, ordinate $y$ or applicate $z$ ), on which the projection of the basis vector is taken. Through the point is given the last symbol that indicates in which basis the corresponding projection is taken.

Unit vector of applicate axis is defined as a vector product of the radius vector $\vec{r}$ and vector $\widehat{k}_{c}$ [17]:

$$
\widehat{k}_{c}=\left\{k_{c . x . m}, k_{c . y . m}, k_{c . z . m}\right\}_{M}=\frac{\vec{r} \times \hat{i}_{c}}{\left|\vec{r} \times \hat{i}_{c}\right|} .
$$

Unit vector of the ordinate axis $\hat{j}_{c}$ forms with $\hat{i}_{c}$ and $\hat{k}_{c}$ right three vectors:

$$
\hat{j}_{c}=\left\{j_{c . x . m}, j_{c . y . m}, j_{c . z . m}\right\}_{M}=\frac{\widehat{k}_{c} \times \hat{i}_{c}}{\left|\widehat{k}_{c} \times \hat{i}_{c}\right|} .
$$

The coupling matrix between CCS and ICS is determined as follows:

$$
K_{C M}^{T}=\left[\begin{array}{lll}
i_{c . x . m} & i_{c . y . m} & i_{c . z . m} \\
j_{c . x . m} & j_{c . y . m} & j_{c . z . m} \\
k_{c . x . m} & k_{c . y . m} & k_{c . z . m}
\end{array}\right] .
$$

TUV Euler angles allow to determine the coordinates in the ICS of the base vector $\hat{j}_{a}$ based on the corresponding coupling matrix [17]:

$$
\begin{aligned}
& \hat{j}_{a}=\{0,1,0\}_{A}=\left\{j_{a . x . m}, j_{\text {a.y.m }}, j_{a . z . m}\right\}_{M} ; \\
& {\left[\begin{array}{lll}
j_{a . x . m} & j_{a . y . m} & j_{a . z . m}
\end{array}\right]^{T}=K_{A M}\left[\begin{array}{lll}
0 & 1 & 0
\end{array}\right]^{T} ;}
\end{aligned}
$$$$
K_{A M}=\left[\begin{array}{ccc}
\cos \varphi \cos \psi & (\sin \varphi \sin \theta- & (\cos \varphi \sin \psi \sin \theta+ \\
& -\cos \varphi \sin \psi \cos \theta) & +\sin \varphi \cos \theta) \\
\sin \psi & \cos \psi \cos \theta & -\cos \psi \sin \theta \\
-\sin \varphi \cos \psi & (\sin \varphi \sin \psi \cos \theta+ & (\cos \varphi \cos \theta- \\
& +\cos \varphi \sin \theta) & -\sin \varphi \sin \psi \sin \theta)
\end{array}\right] .
$$

Next, let's find the coordinates of the basis vector $\hat{j}_{a}$ in the CCS base:

$$
\left[\begin{array}{lll}
j_{a . x . c} & j_{a . y . c} & j_{a . z . c}
\end{array}\right]^{T}=K_{C M}^{T}\left[\begin{array}{lll}
j_{a . x . m} & j_{a . y . m} & j_{a . z . m}
\end{array}\right]^{T} .
$$

The vector $\vec{j}_{a}^{\prime}$ is formed on the basis of the unit vector $\widehat{j}_{a}$ coordinates in the CCS:

$$
\vec{j}_{a}^{\prime}=\left\{0, j_{a . y . c}, j_{a . z . c}\right\}_{C} .
$$

The pseudo-roll angle is defined using the $f_{\text {polar }}(\cdot)$ function:

$$
\theta^{\prime}=f_{\text {polar }}\left(j_{\text {a.y.c. }}, j_{\text {a.z.c }}\right) \text {. }
$$

To control the absolute value $\vec{F}_{p}$ let's introduce a pseudopitch angle $\psi^{\prime}$. It is formed between the $O_{a} x_{a}$ axis of the ICS and the vector $\vec{i}_{m}^{\prime}$ (Fig. $3, b$ ). The vector $\vec{i}_{m}^{\prime}$ is a projection of the basis vector $\hat{i}_{m}$ on the $x_{a} O_{a} y_{a}$ plane of the BCS:

$$
\begin{aligned}
& \overrightarrow{i_{m}^{\prime}}=\left\{i_{m . x}, i_{m . y}, 0\right\}_{A} ; \\
& {\left[\begin{array}{lll}
i_{m . x} & i_{m . y} & i_{m . z}
\end{array}\right]^{T}=K_{A M}^{T}\left[\begin{array}{lll}
1 & 0 & 0
\end{array}\right]^{T},}
\end{aligned}
$$

where $i_{m . x}, i_{m . y}, i_{m . z}$ - the coordinates of the base vector $\hat{i}_{m}$ in the BCS; $K_{A M}$ - coupling matrix between BCS and ICS.

Let's find the pseudo-pitch angle $\psi^{\prime}$ using the $f_{\text {polar }}(\cdot)$ function:

$$
\psi^{\prime}=-f_{\text {polar }}\left(i_{m . x}, i_{m . y}\right) .
$$

For small $\beta$, the minus sign gives negative values of $\psi^{\prime}$ when pitching to the bow, and positive values when pitching to the stern, thus, the signs of $\psi^{\prime}$ and $\psi$ coincide. This will allow not to make changes to the rotational motion controller.

The translational controller will consist of a $\beta$-controller and a $\rho$-controller, designed to control the TUV polar translational coordinates, respectively, $\beta$ and $\rho$ in the $O_{m} y_{m} z_{m}$ plane of the ICS. Also, it includes a coordinate generation unit that performs the conversion of the specified $\left\{y_{g}, z_{g}\right\}$ and actual $\{y, z\}$ TUV Cartesian coordinates to the specified $\left\{\beta_{g}, \rho_{g}\right\}$ and actual $\{\beta, \rho\}$ polar coordinates (Fig. 4).

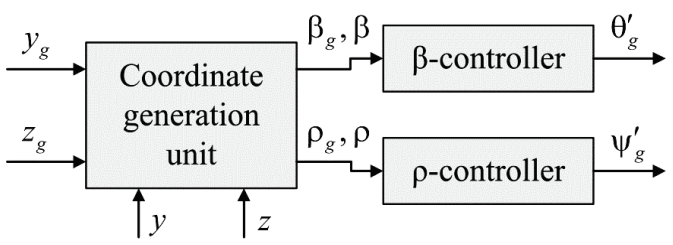

Fig. 4. The generalized structure of the towed underwater vehicle translational motion controller

The control law (1) will be taken as the basis for the synthesis of $\beta$ - and $\rho$-controllers. Let's coordinate the work of $\beta$ - and $\rho$-controllers as follows. Since the pseudo-pitch $\psi^{\prime}$ allows controlling the absolute value of the control vector $\vec{F}_{p}$, let's eliminate the error in the parameter $\rho$ after the error in the parameter $\beta$ is reduced to some small value:

$$
\rho_{g}=\left\{\begin{array}{l}
L, \text { if }\left|\beta_{g}-\beta\right| \leq \varepsilon_{\beta}, L=\text { const; } \\
\sqrt{y_{g}^{2}+z_{g}^{2}}, \text { otherwise }
\end{array}\right.
$$

where $L$ - the length of the cable tug; $\varepsilon_{\beta}$ - the value of the error in the parameter $\beta$, at which the $\rho$-controller begins to work out the error in $\rho$.

The value of $\rho=L$ is inaccessible to the TUV, therefore, the absolute value of $\vec{F}_{p}$ will be kept maximum, while the error in the parameter $\beta$ is eliminated. In this regard, the control circuit for the parameter $\beta$ has a higher priority than the control circuit for the parameter $\rho$.

The time constant of the reference model for rotational motion regulators was chosen $0.5 \mathrm{~s}$. The time constant for controllers of translational motion we will choose 
several times higher than the time constant of the reference model of rotational motion controllers. The parameter $h$ is chosen so that the loop of the control function is a secondorder aperiodic link [20]. The parameter $k$ (and the rest of the system parameters) will be selected using simulation modeling of the dynamics of the TUV translational motion. The selected parameters of the controllers are summarized in Table 1.

Table 1

Parameters of the controllers of towed underwater vehicle spatial motion automatic control system

\begin{tabular}{|c|c|c|c|c|}
\hline Parameter & $\beta$-controller & $\rho$-controller & $\theta^{\prime}$-controller & $\psi^{\prime}$-controller \\
\hline$T_{r,} \mathrm{~s}$ & 3 & 3.5 & 0.5 & 0.5 \\
\hline$c$ & 5 & 5 & 5 & 5 \\
\hline$k$ & $2.08, \mathrm{deg} / \mathrm{m}$ & $3.06, \mathrm{deg} / \mathrm{m}$ & $1, \mathrm{deg}^{-1}$ & $2, \mathrm{deg}^{-1}$ \\
\hline$h_{,} \mathrm{s}^{-1}$ & 3.33 & 2.86 & 20 & 20 \\
\hline$\sigma$ & 1 & -1 & 1 & 1 \\
\hline$K_{S}$ & 1.01 & 1.01 & 1.06 & 1.06 \\
\hline$\varepsilon_{\beta}$, deg. & \multicolumn{2}{|c|}{10} & \multicolumn{3}{|c|}{-} \\
\hline$\kappa$, deg. & 90 & 45 & \multicolumn{3}{|c|}{} \\
\hline
\end{tabular}

All system controllers operate on the basis of control law (1), which calculates the control action $u \in[-1,1]$. The outputs of the $\beta$ and $\rho$ controllers are calculated as follows:

$$
\theta_{g}^{\prime}=u_{\beta} \kappa_{\beta} ; \quad \psi_{g}^{\prime}=u_{\rho} \kappa_{\rho},
$$

where $u_{\beta}, u_{\rho}$ - parameters that are calculated according to the $\beta$ and $\rho$ controllers on the basis of law (1); $\kappa_{\beta}, \kappa_{\rho}-$ proportionality coefficients for, respectively, $\beta$ - and $\rho$-controllers, their numerical values are given in Table 1 .

The selected controller parameters (Table 1) give high dynamic control accuracy with a sinusoidal control task and a small overshoot during a step change in the control task under uncertainty conditions.

\section{Research results}

As part of the work, a study of the synthesized ACS under uncertainty conditions by a simulation method using a specialized modeling complex [6] was conducted. Fig. 5 shows transients at a towing speed of $1 \mathrm{~m} / \mathrm{s}$ and a step change in the control task.

As it is possible to see in Fig. 5, the synthesized ACS of the TUV spatial motion ensures the elimination of the control error and the maintenance of the unit at the given point under uncertainty conditions. During the transition between the given translational coordinates, the TUV's depth decreases and, first of all, the error in the lateral coordinate $z$ (Fig. 5, a) is eliminated, since the polar coordinate $\beta$ (Fig. $5, b$ ) has a higher priority than the polar coordinate $\rho$ (Fig. 5, c). The automatic control system of the TUV rotational motion ensures the working off of the given values of the pseudoroll $\theta^{\prime}$ and the pseudo-pitch $\psi^{\prime}$ (Fig. 5, $d, e$ ).
Let's study the TUV spatial motion with a harmonious change in the control task and the towing speed of $3 \mathrm{~m} / \mathrm{s}$ (Fig. 6).

With a harmonious change of the control task, the ACS provides a high dynamic control accuracy if it does not fall into the saturation zone (Fig. 6, a). When a control error occurs, for example, after entering the saturation zone, the ACS eliminates it. Small deviations (up to $0.3 \mathrm{~m}$ ) of the $y$ coordinate from its given constant value are observed, due to the fact that a change in the lateral $z$ coordinate leads to the occurrence of disturbances along the vertical $y$ coordinate.

The polar coordinates of the unit are shown in Fig. 6, $b, c$. The outputs of the $\beta$ - and $\rho$-controllers, as well as the actual values of the pseudo-roll and pseudo-pitch are presented in Fig. 6, $d, e$ and allow to estimate whether the ACS is in the saturation zone at certain points in time.

The dynamics of the TUV spatial motion ACS operation was studied at various towing speeds in the range from $1 \mathrm{~m} / \mathrm{s}$ to $3 \mathrm{~m} / \mathrm{s}$. The overshoot does not exceed $0.8 \mathrm{~m}$, the duration of transient processes from the moment of leaving the saturation zone to the moment the control error falls within a range of $\pm 0.5 \mathrm{~m}$ does not exceed $6 \mathrm{~s}$, which corresponds to the given control task under uncertainty. Synthesized ACS provides ample dynamic control accuracy of the TUV.
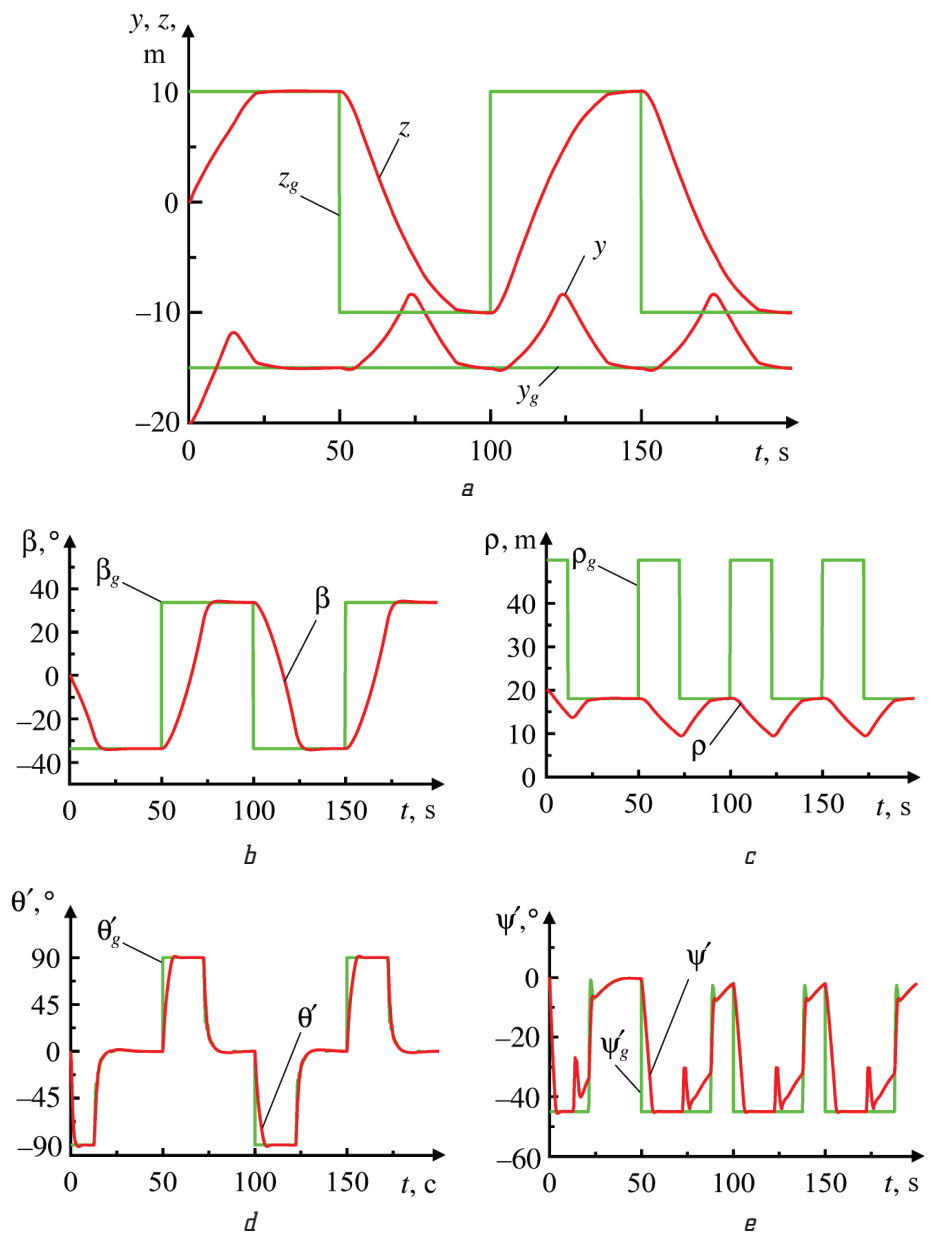

Fig. 5. The results of the simulation of the towed underwater vehicle (TUV) spatial motion automatic control system with a step change in the control task: $a$ - TUV translational Cartesian coordinates; $b$ - polar coordinate $\beta$; $c$ - polar coordinate $\rho ; d$ - TUV pseudo-roll; $e$ - TUV pseudo-pitch 

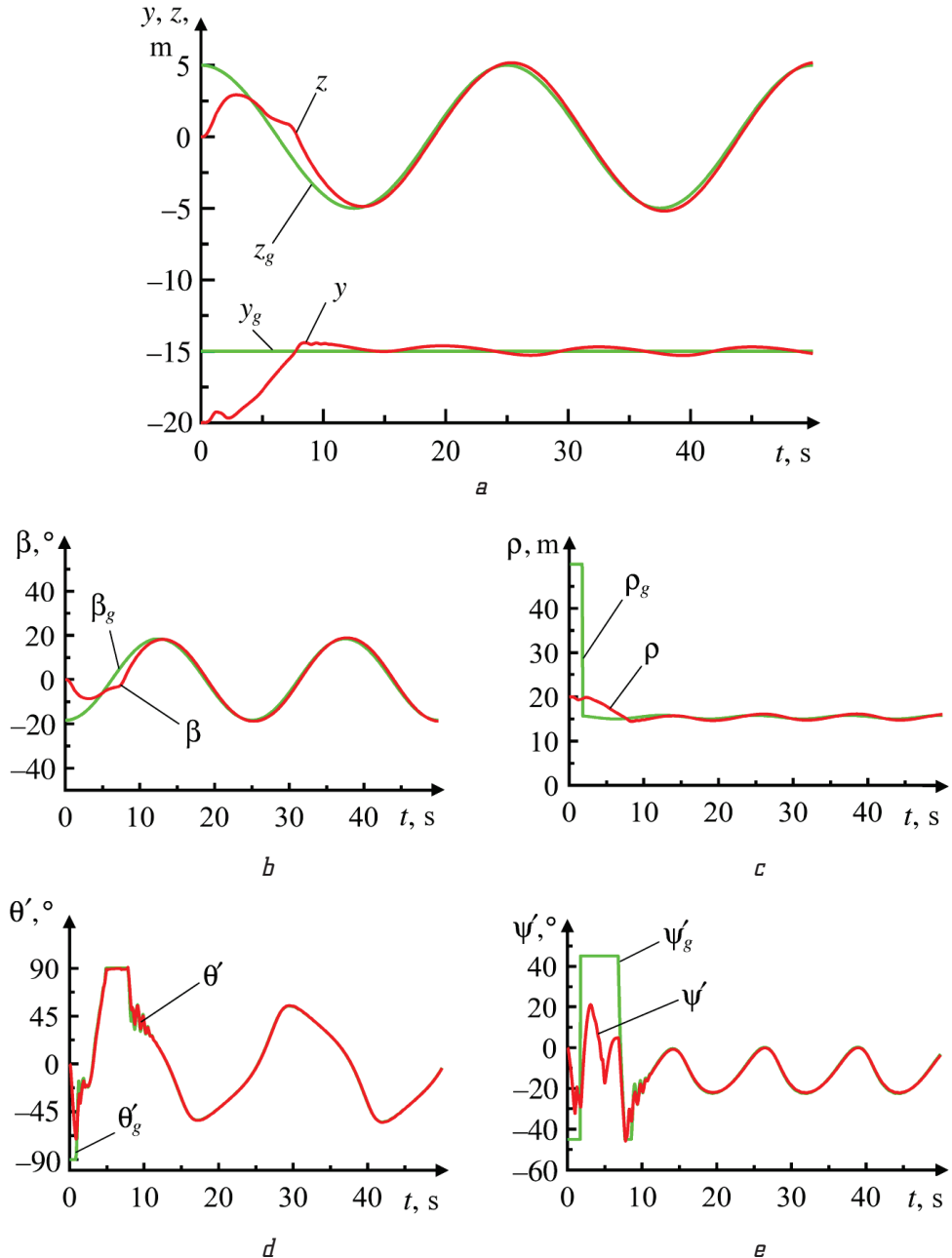

Fig. 6. The results of the simulation of the towed underwater vehicle (TUV) spatial motion automatic control system with a harmonious change in the control task: $a$ - TUV translational Cartesian coordinates; $b$ - polar coordinate $\beta ; c-$ polar coordinate $\rho$; $d$ - TUV pseudo-roll; $e$ - TUV pseudo-pitch

\section{SWOT analysis of research results}

Strengths. The synthesized ACS operates under uncertainty and provides sufficient dynamic control accuracy. In contrast to the well-known ACSs of underwater vehicles, information on the structure and parameters of the mathematical model of the control object is not needed for its synthesis. As part of the ACS, the control law is used, which does not require information on derivatives of a controlled quantity. This allows to simplify the feedback loops and improve the quality of the synthesized automatic control system compared to the ACSs, which use all the coordinates of the phase space of the control object. In this case, the effect of high amplitude switching of control actions in the synthesized ACS can be observed only in some cases in the saturation mode, in contrast to the ACSs operating in the sliding mode.

Weaknesses. In the operation of the synthesized ACS, there is a slight overshoot after leaving the saturation zone. It is also not optimal for the duration of transients. A decrease in the time constants of the reference models may lead to an increase in overshoot.

Opportunities. The prospect of further research is elimination of the overshoot and in accordance with the ACS of the TUV and the TB for the purpose of controlled motion with stabilization of the TUV's height above the ground.

The introduction of synthesized ACS TUV in standard TUS equipment will significantly reduce the load on the TUV operators and is the basis for long-term underwater missions.

Threats. The theory of automatic control of nonlinear objects continues to evolve. The use of intelligent control technologies under uncertainties in the future can replace the synthesized ACS. However, this requires not only the development of intelligent control technologies, but also the availability of computing resources for their implementation.

For the introduction of a synthesized ACS, the use of typical computing resources sufficient to solve systems of differential equations using numerical methods is sufficient.

\section{Conclusions}

1. Controllers of translational and rotating controlled parameters of the towed underwater vehicle are synthesized in the polar coordinate system. The synthesis is carried out on the basis of the control law with the minimization of local functionals and the adjustment of the initial conditions. The resulting controllers are the basis for the synthesis of the automatic control system for the towed underwater vehicle spatial motion.

2. The automatic control system of towed underwater vehicle spatial motion is synthesized on the basis of the developed block of formation of coordinates, controllers of translational and rotational motions. It provides control with the vertical and lateral coordinates of the towed underwater vehicle without the use of derived controlled quantities under uncertainty with sufficient dynamic accuracy.

3 . The operation of the synthesized automatic control system for the translational motion of the towed underwater vehicle is studied by computer simulation under uncertainty at towing speeds from $1 \mathrm{~m} / \mathrm{s}$ to $3 \mathrm{~m} / \mathrm{s}$. The overshoot does not exceed $0.8 \mathrm{~m}$, the duration of transient processes outside the saturation zone does not exceed $6 \mathrm{~s}$. The simulation results show quite satisfactory dynamic accuracy of the controlled parameters following the control task after the control error is eliminated.

\section{References}

1. Egorov V. I. Podvodnye buksiruemye sistemy: textbook. Leningrad: Sudostroenie, 1981. 304 p.

2. Ikonnikov I. B., Gavrilov V. M., Puzyrev G. V. Podvodnye buksiruemye sistemy i bui neytral'noy plavuchesti. Saint Petersburg: Sudostroenie, 1993. 224 p.

3. Fossen T. I. Handbook of marine craft hydrodynamics and motion control. Norway: John Wiley \& Sons Ltd, 2011. 596 p. doi: http://doi.org/10.1002/9781119994138

4. Dinamika podvodnykh buksiruemykh sistem / Poddubnyy V. I et. al. Saint Petersburg: Sudostroenie, 1995. 200 p.

5. Dudykevych V., Blintsov O. Tasks statement for modern automatic control theory of underwater complexes with flexible tethers // Eureka: Physics and Engineering. 2016. Issue 5. P. 25-36. doi: http://doi.org/10.21303/2461-4262.2016.00158 
6. Blintsov O. V., Sokolov V. V. Specialized simulating complex for studying motion dynamics of the towed underwater system // Collection of Scientific Publications NUS. 2017. Vol. 3. P. 63-69. doi: http://doi.org/10.15589/jnn20170308

7. Minowa A., Toda M. A High-Gain Observer-Based Approach to Robust Motion Control of Towed Underwater Vehicles // IEEE Journal of Oceanic Engineering. 2018. P. 1-14. doi: http:// doi.org/10.1109/joe.2018.2859458

8. Robust automatic control system of vessel descent-rise device for plant with distributed parameters «cable - towed underwater vehicle» / Chupina K. V. et. al. // Journal of Physics: Conference Series. 2018. Vol. 1015. P. 032167. doi: http://doi.org/ $10.1088 / 1742-6596 / 1015 / 3 / 032167$

9. Heading control of ROV ROSUB6000 using non-linear modelaided PD approach / Ramesh R. et. al. // International Journal of Emerging Technology and Advanced Engineering. 2013 Vol. 3, Issue 4. P. 382-393.

10. Soltan R. A., Ashrafiuon H., Muske K. R. ODE-based obstacle avoidance and trajectory planning for unmanned surface vessels // Robotica. 2010. Vol. 29, Issue 5. P. 691-703. doi: http://doi.org/ $10.1017 / \mathrm{s} 0263574710000585$

11. Modelling, Design and Robust Control of a Remotely Operated Underwater Vehicle / Garcia-Valdovinos L. G. et. al. // International Journal of Advanced Robotic Systems. 2014. Vol. 11, Issue 1. P. 1-16. doi: http://doi.org/10.5772/56810

12. Bessa W. M., Dutra M. S., Kreuzer E. Depth control of remotely operated underwater vehicles using an adaptive fuzzy sliding mode controller // Robotics and Autonomous Systems. 2008. Vol. 56, Issue 8. P. 670-677. doi: http://doi.org/10.1016/j.robot.2007.11.004

13. Bessa W. M., Dutra M. S., Kreuzer E. Dynamic positioning of underwater robotic vehicles with thruster dynamics compensation // International Journal of Advanced Robotic Systems. 2013. Vol. 10, Issue 9. P. 325. doi: http://doi.org/10.5772/56601

14. Tam D. Ch. Experimental research of a towed underwater vehicle altitude automatic control system // Technology Audit and Production Reserves. 2013. Vol. 5, Issue 5 (13). P. 29-31. doi: http://doi.org/10.15587/2312-8372.2013.18381

15. Nadtochii V. A. Self-propelled underwater system control integration within maritime technological complex // Eastern-European Journal of Enterprise Technologies. 2013. Vol. 5, Issue 4 (65). P. 40-45. URL: http://journals.uran.ua/eejet/article/view/18342
16. Output feedback motion control system for observation class ROVs based on a high-gain state observer: theoretical and experimental results / Fernandes D. A. et. al. // Control Engineering Practice. 2015. Vol. 39. P. 90-102. doi: http://doi.org/ 10.1016/j.conengprac.2014.12.005

17. Blintsov O. V. Systemy avtomatychnoho keruvannia rukhom pidvodnykh kompleksiv z hnuchkymy zviazkamy: navchalnyi posibnyk. Mykolaiv: Natsionalnyi universytet korablebuduvannia imeni admirala Makarova, 2018. 251 p.

18. Blintsov $\mathrm{O}$. Formation of a reference model for the method of inverse dynamics in the tasks of control of underwater complexes // Eastern-European Journal of Enterprise Technologies. 2016. Vol. 4, Issue 2 (82). P. 42-50. doi: http://doi.org/ 10.15587/1729-4061.2016.74875

19. Lukomskiy Yu. A., Peshekhonov V. G., Skorokhodov D. A Navigatsiya i upravlenie dvizheniem sudov: textbook. Saint Petersburg: Elmor, 2002. 360 p.

20. Krut'ko P. D. Obratnye zadachi dinamiki v teorii avtomaticheskogo upravleniya. Tsikl lektsiy: textbook. Moscow: Mashinostroenie, 2004. 576 p.

21. Blintsov O. V., Sokolov V. V., Korytskyi V. I. Avtomatychne keruvannia bezekipazhnym pidvodnym kompleksom systemy monitorynhu akvatorii v umovakh nevyznachenosti: proceeding // Suchasni problemy informatsiinoi bezpeky na transporti. 2018 P. $19-26$.

Blintsov Volodymyr, Doctor of Technical Science, Professor, Vice Rec tor for Scientific Work, Admiral Makarov National University of Shipbuilding, Mykolayiv,Ukraine,e-mail:volodymyr.blintsov@nuos.edu.ua, ORCID: http://orcid.org/0000-0002-3912-2174

Blintsov Oleksandr, Doctor of Engineering Sciences, Associate Professor, Department of Computer Technologies and Information Security, Admiral Makarov National University of Shipbuilding, Mykolayiv, Ukraine, e-mail: alex_blintsov@ukr.net, ORCID: http://orcid.org/ 0000-0003-0426-1219

Sokolov Volodymyr, Chief Engineer, First Deputy General Director State Enterprise «Production Association «O. M. Makarov Southern Machinebuilding Plant»,Dnipro,Ukraine,e-mail: sokolow@yuzhmash.com, ORCID: http://orcid.org/0000-0002-7015-0464 